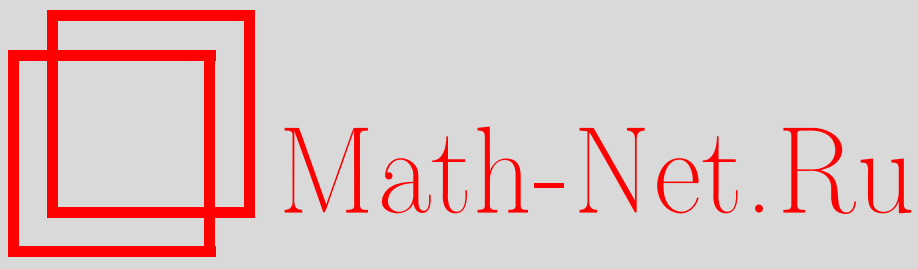

В. В. Ульянов, Коллоквиум в Билефельдском университете, Теория вероятн. и ее примен., 2000, том 45, выпуск 1, 203

DOI: https://doi.org/10.4213/tvp340

Использование Общероссийского математического портала Math-Net.Ru подразумевает, что вы прочитали и согласны с пользовательским соглашением http://www . mathnet.ru/rus/agreement

Параметры загрузки:

IP : 34.229 .108 .108

26 апреля 2023 г., 14:34:42

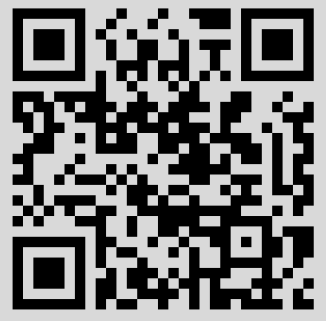




\section{КОЛЛОКВИУМ В БИЛЕФЕЛЬДСКОМ УНИВЕРСИТЕТЕ}

16 декабря 1999 г. в Билефельдском университете, Германия, прошел коллоквиум, организованный видным немецким математиком проф. Ф. Гётце и посвященный 70-летию выдағоегося российского ученого акад. РАН Ю.В. Прохорова. С часовыми докладами выступили:

А. А. Боровков «Большие уклонения для случайных блужданий, шаг которых имеет распределение с регулярными хвостами»,

И. А. Ибрагимов «О восстановлении аналитических функций»,

Ю. В. Прохоров «О формуле суммирования Пуассона»,

В. ван Цвет «О состоятельном оценивании».

В работе коллоквиума приняли участие математики из 8 стран, в частности: Р. Алсведе, В. Бенткус, В.И. Берник, В.И. Богачев, А. Ю. Зайцев, Г. Кристоф, 3. М. Ма, А. Рачкаускас, М. Рекнер, А. Н. Тихомиров, В. В. Ульянов, Л. Хачатрян, Г. П.Чистяков, Г. Цессип, П. Эйхельсбехер, А. А. Юдин.

B. B. УЛЬЯнов

\section{ИНФОРМАЦИЯ О РАБОТЕ БОЛЬШОГО СЕМИНАРА КАФЕДРЫ ТЕОРИИ ВЕРОЯТНОСТЕЙ МЕХАНИКО-МАТЕМАТИЧЕСКОГО ФАКУЛЬТЕТА МГУ}

Семинар является продолжением научно-исследовательсхого семинара кафедры теории вероятностей под руководством А. Н. Колмогорова и Б. В. Гнеденко.

В настояшее время руководителем семинара является чл.-корр. РАН профессор A. Н. Ширяев.

Заседания семинара проходят по средам с 16 ч. 20 мин. в аудитории 16-24 главного здания МГУ. Продолжительность доклада -60 минут. Первая часть содержит введение в рассматриваемую область, а вторая часть посвящена изложению полученных результатов. Заяки на доклады представляются на кафедру теории вероятностей ученому секретарю семинара. Обсужденде деталей доклада и епо возможных сроков производится с координатором семинара. С текущей информацией о работе семинара можно ознакомиться на кафедре теории вероятностей (тел. 939-14-03), на кафедре математической статистики факультета ВМиК МГУ, а также в отделе теории вероятностей МИ РАН им. В.А. Стеклова.

В осеннем семестре 1999 года были представлены доклады по следуюшим темам: статистика случайных процессов, финансовая математика, теория статистического оценивания, большие уклонения, физические приложения теории вероятностей. Ниже приводится полный список докладов.

8 сентября - Я. Г. Синай (Москва) Стохастический анализ дияамики адиабатического порикя. 